\title{
MAPS, ILLUSTRATIONS, AND TABLES
}

\section{MAPS}

1. Expansion of the urban area, metropolitan region of São Paulo, 1949-1992

2. Average monthly income of heads of households, metropolitan region of São Paulo, 1991

3. Districts of the municipality of São Paulo

4. Municipalities of the metropolitan region of São Paulo

\section{FIGURES}

1. Rates of crime per 100,000 population, metropolitan region of São Paulo, 1973-1996

2. Rates of total crime per 100,000 population, 1973-1996

3. Rates of violent crime, municipality of São Paulo and other municipalities, 1981-1996

4. Rates of selected crimes against persons, metropolitan region of São Paulo, 1981-1996

5. Rates of murder, municipality of São Paulo and other municipalities, 1981-1996

6. Evolution of murder registration, municipality of São Paulo and other municipalities, 1981-1996

7. Rates of larceny and robbery, municipality of São Paulo and other municipalities, 1981-1996

\section{PHOTOGRAPHS}

1. Consolação, central São Paulo, 1980

2. Jardim das Camélias, $1980 \quad 23 x$ 
3 and 4 . Street in Jardim das Camélias, 1980 and 1989 238,239

5 and 6. Portal do Morumbi, 1994

246,247

7. Morumbi, unequal neighbors, 1992

248

8. Morumbi, aerial view, 1992

249

9. High-security façade in Morumbi, 1994

292

10. Autoconstructed houses in Jardim das Camélias, 1994

293

11. Old working-class row houses in Moóca, 1989

294

12. Façades in Moóca, 1989

294

13. Façades in Moóca, 1989

\section{TABLES}

1. Yearly inflation, Brazil, 1980-1998

2. Brazilian categories of crime statistics and English translations

116

3. Murders by source, 1981-1996

123

4. Deaths and injuries in military police actions, $1981-1997$

162

5. Punishment of civil policemen, 1981-1988, 1991-1993

168

6. Military policemen dismissed and expelled, 1981-1993

169

7. Evolution of the population, city of São Paulo and metropolitan region, $1872-1996$

8. Socioeconomic indicators, 1980 and 1991, city of São Paulo and its poorest periphery 